\title{
Urban spatial structure re-identification as an approach to solving urban transport problem (A case study in Malang)
}

\author{
Dadang Meru Utomo ${ }^{1, *}$, and Septiana Hariyani $^{1}$ \\ ${ }^{1}$ Brawijaya University, Urban and Regional Planning Department, Malang, Indonesia
}

\begin{abstract}
In an effort to solve the congestion problem, the local government of Malang City has taken various steps. However, unfortunately, the result has not been effective. This shows that the efforts that have been taken so far are sectoral, therefore a more comprehensive approach is needed in order to reach a more effective result. This research aims at re-evaluating the determination of Malang City's urban spatial structure through the delineation of narrower units of area using the centrality index method. The research suggests that urban spatial structures have a very clear pattern of association with congestion locations. It can be concluded that the local government of Malang City needs to put more consideration on evaluating the urban spatial structure to solve the problem of transportation which is ever-growing the in second largest urban area in East Java Province.
\end{abstract}

\section{Introduction}

Traffic problems that haunt almost all big cities in Indonesia, including Malang in East Jawa Province, are mostly due to the imbalance between the growth of private vehicle use and the inadequate provision of transport infrastructure. As the second biggest urban area in the province, Malang has attracted high traffic for its strategic location adjacent to the country's most touristic city of Batu, its wide stretch of natural beaches in its southern part, and its vibrant city life. The ever-growing traffic has admittedly brought transport problems in need of serious attention.

The local government of Malang, reportedly, has attempted several different approaches to solving its transport problem. The approaches include traffic management strategy, provision of new road infrastructure, as well as public transport provision [1]. However, it seemed that the aforementioned transport solutions have not been fully effective, as seen in many prevalent traffic hot-spots during the city's busy hours and especially during the weekends. Also, the ownership of private vehicles has been reported to grow steadily in the last couple of years [2]. Another problem related to transport in Malang is the increase of road accidents, according to official reports. It is therefore an urgent situation for the local

\footnotetext{
* Corresponding author: dadang.utomo@ub.ac.id
} 
government and transport planners to think of a more comprehensive and sustainable approach to stopping the problem to cause further externalities.

Several scholars have come to an idea of looking at the problem from a more holistic perspective, which is by evaluating the urban spatial structure. An effective spatial structure of a city will lead to a less-decentralized pattern of movement towards a single city center [3]. A spatial urban structure approach is an alternative to improving environmental qualities through the provision of different urban facilities and infrastructure, one of which is the efficiently planned transportation to support sustainability [4]. In addition, the correlation between urban spatial structure and transport has been justified through empirical research; traffic generation models help explain the spatial distribution of space in an urbanized area [5]. Furthermore, the miles driven and travel choices depend on the spatial structure in which a person lives [6]. These explanations justify the fact that a positive correlation between urban spatial structure and travel patterns does exist. In an Indonesian context, supports that there has been a scientific correlation between travel patterns and the spatial distribution of land-use which forms the urban structure [7]. And then comes the question, which urban structure is the most effective for alleviating transport problems in cities?

A multinucleated or polycentric type of urban spatial structure leads to an efficiency of energy used in transport, compared to a more single-centered type of spatial structure [8]. In the same light, the research find that the evenly distribution of facilities, argued as an effective urban structure, allows shorter trips, cuts down the consumption of fuel energy, and minimizes the potential of accidents $[3,4]$. In many cases, it also increases the number of mode shifts to public or active transport. Building upon these findings, it can be said that urban spatial structure could be a more appropriate approach to a better transport treatment, thus alleviate the ever-worsening transport problem in Malang.

In terms of development, Malang has undergone a significantly rapid urbanization in the last couple of decades. Sub-urbans, known as kecamatan, have been provided with a wide range of facilities with supposedly better road infrastructure. This has arguably been a strong reason for the increase of movements within the city. With so many points of traffic congestion in Malang, it seems that there has not been an adequate prioritization of improvement. This is probably due to the lack of consideration of urban structure in formulating the strategy to improve the transport condition.

A clear picture of the city's urban structure is explained in the Spatial Plan document (RTRW). The classification of the structure hierarchy is based on the population density, road infrastructure availability, and the availability of facilities. Kecamatan Klojen has been designated as the city centre, whilst the other five kecamatan being sub-centres. This classification of urban structures, theoretically, should be able to evenly distribute movement, thus avoid overburdening any particular roads. However, looking at the transport problems which are apparent in many parts of the city, it is hypothetically stated that the existing urban structure should be carefully reclassified. This paper, therefore looks at assessing the urban spatial structure to suggest a better solution for the city's transport problem.

\section{Methods}

In assessing the accuracy in the classification of urban structure in Malang, this research adopts the similar approach to what the RTRW is using, known as the centrality index. This approach calculates the number of facilities and population density in a given unit of area. The unit of area, noted as BWP, with higher calculation of centrality becoming a unit of area with a higher hierarchy of structure. Tabel 1 explains the delineation of each BWP in 
Malang. This research assumes that the current designation of BWPs is too vague, thus prioritization of transport solution seemed to be inaccurate.

\subsection{Location}

In the hope to formulate a better transport prioritization, this research re-classifies the aforementioned BWP classification into smaller-sized BWPs. The reclassification is done based on the sub-urban administrative adjacency. Table 2 explains the reclassification of unit of area in Malang.

Table 1. Malang's delineation of sub-urbans

\begin{tabular}{|c|l|}
\hline $\begin{array}{c}\text { Number } \\
\text { of BWP }\end{array}$ & \multicolumn{1}{c|}{ Sub-urban area coverage } \\
\hline 1 & $\begin{array}{l}\text { Merjosari, Dinoyo, Sumbersari, Ketawanggede, Jatimulyo, Lowokwaru, } \\
\text { Tulusrejo, Mojolangu, Tunjungsekar, Tasikmadu, Tunggulwulung, } \\
\text { Tlogomas, Penanggungan }\end{array}$ \\
\hline 2 & $\begin{array}{l}\text { Bunulrejo, Purwantoro, Pandanwangi, Blimbing, Purwodadi, Polowijen, } \\
\text { Arjosari, Balearjosari }\end{array}$ \\
\hline 3 & $\begin{array}{l}\text { Bandungrejosari, Bakalan Kerajan, Mulyorejo, Bandulan, Tanjungrejo, } \\
\text { Pisang Candi, Karangbesuki }\end{array}$ \\
\hline 4 & $\begin{array}{l}\text { Kasin, Sukoharjo, Kidul Dalem, Kauman, Bareng, Gading Kasri, Oro-Oro } \\
\text { Dowo, Klojen, Rampal Celakat, Samaan }\end{array}$ \\
\hline 5 & $\begin{array}{l}\text { Kedungkandang, Sawojajar, Madyopuro, Lesanpuro, Cemorokandang, } \\
\text { Jodipan, Polehan, Kesatrian }\end{array}$ \\
\hline 6 & $\begin{array}{l}\text { Arjowinangun, Tlogowaru, Wonokoyo, Bumiayu, Buring, Mergosono, } \\
\text { Kotalama, Kebonsari, Gadang, Ciptomulyo, Sukun, Bandungrejosari }\end{array}$ \\
\hline
\end{tabular}

Table 2. Proposed Malang's delineation of sub-urbans

\begin{tabular}{|c|l|}
\hline $\begin{array}{c}\text { Number } \\
\text { of BWP }\end{array}$ & \multicolumn{1}{|c|}{ Sub-urban area coverage } \\
\hline 1 & $\begin{array}{l}\text { Dinoyo, Ketawang Gede, Merjosari, Tlogomas, Penanggungan, } \\
\text { Sumbersari }\end{array}$ \\
\hline 2 & $\begin{array}{l}\text { Tulusrejo, Tunggul Wulung, Tunjung Sekar, Jatimulyo, Lowokwaru, } \\
\text { Mojolangu, Tasikmadu }\end{array}$ \\
\hline 3 & $\begin{array}{l}\text { Polowijen, Purwodadi, Arjosari, Balearjosari, Blimbing, Bunulrejo, } \\
\text { Purwantoro, Pandanwangi }\end{array}$ \\
\hline 4 & Polehan, Jodipan, Ksatrian, Sawojajar \\
\hline 5 & Lesanpuro, Madyopuro, Cemoro Kandang, Kedungkandang \\
\hline 6 & Kauman, Klojen, Sukoharjo, Kasin, Rampal Celaket, Kidul Dalem \\
\hline 7 & Bareng, Gading Kasri, Oro-Oro Dowo, Sama'an \\
\hline 8 & $\begin{array}{l}\text { Bandulan, Karang Besuki, Mulyorejo, Pisang Candi, Tanjungrejo, } \\
\text { Bakalankrajan }\end{array}$ \\
\hline 9 & $\begin{array}{l}\text { Kebonsari, Sukun, Ciptomulyo, Mergosono, Bandungrejosari, Gadang, } \\
\text { Kota Lama }\end{array}$ \\
\hline 10 & Arjowinangun, Tlogowaru, Wonokoyo, Bumiayu, Buring \\
\hline
\end{tabular}

\section{Result and discussion}

The Spatial Plan of Malang (RTRW Kota Malang 2010-2030) has divided its area into six units of area based on the spatial distribution of public facilities, population density, and the availability of transport infrastructure. Table 3 explains in more detail the calculation of the BWP hierarchy based on the classification in Malang's RTRW. 
Table 3. The actual structure centrality index calculation

\begin{tabular}{|c|c|c|c|c|c|c|c|c|}
\hline \multirow{2}{*}{ BWP } & \multicolumn{2}{|c|}{$\begin{array}{c}\text { Population } \\
\text { density }\end{array}$} & \multicolumn{2}{c|}{ Facility density } & \multicolumn{2}{c|}{$\begin{array}{c}\text { Road infrastructure } \\
\text { availability }\end{array}$} & \multicolumn{2}{c|}{$\begin{array}{c}\text { Indeks } \\
\text { Sentralitas }\end{array}$} \\
\cline { 2 - 9 } & Score & Class & Score & Class & Score & Class & Score & Rank \\
\hline 1 & 89 & Low & 16 & Low & 161,36 & High & 0,88 & 3 \\
\hline 2 & 90 & Low & 18 & Low & 177,18 & High & 1,01 & 2 \\
\hline 3 & 82 & Low & 17 & Low & 143,88 & High & 0,73 & 4 \\
\hline 4 & 143 & Medium & 27 & Medium & 155,22 & High & 2,25 & 1 \\
\hline 5 & 65 & Low & 10 & Low & 132,90 & High & 0,72 & 5 \\
\hline 6 & 56 & Low & 8 & Very Low & 91,67 & High & 0,55 & 6 \\
\hline
\end{tabular}

Based on the calculation, it can be seen that BWP 4 is statistically positioned at the highest hierarchy of centres of the city's spatial structure, while the remaining five BWPs are designated as sub-centres. For the purpose of delivering transport strategies, this current classification seems to be too vogue as it fails to fully identify specific locations of transport hot-spots. Logically, a greater generation of traffic which means a greater possibility of traffic congestion will be attracted towards the higher hierarchies. However, the current hierarchy calculation does not accurately show transport improvement priority. For example, the heavy traffic in the area of Ketawanggede and Dinoyo of BWP 1 is admittedly much more in need of transport solution than in Blimbing of BWP 2. As being hypothesized at the beginning of this research, this relatively inaccurate method of delineation contributes to the inaccurate strategy of transport. Therefore, this research hopes to assess the urban spatial structure using smaller units of area. Table 4 explains the detailed calculation of proposed urban structure.

Table 4. The actual structure centrality index calculation

\begin{tabular}{|c|c|c|c|c|c|c|c|c|}
\hline \multirow{2}{*}{ Zone } & \multicolumn{2}{|c|}{ Population density } & \multicolumn{2}{|c|}{ Facility density } & \multicolumn{2}{c|}{$\begin{array}{r}\text { Road infrastructure } \\
\text { availability }\end{array}$} & \multicolumn{2}{c|}{$\begin{array}{c}\text { Indeks } \\
\text { Sentralitas }\end{array}$} \\
\cline { 2 - 9 } & Score & Class & Score & Class & Score & Class & Score & Rank \\
\hline 1 & 104 & Medium & 18 & Low & 155.09 & High & 13.10 & 5 \\
\hline 2 & 77 & Low & 15 & Low & 165.49 & High & 11.68 & 6 \\
\hline 3 & 93 & Low & 18 & Low & 177.18 & High & 19.51 & 2 \\
\hline 4 & 138 & Medium & 26 & Medium & 219.33 & High & 8.24 & 9 \\
\hline 5 & 41 & Low & 5 & Very Low & 106.03 & High & 9.30 & 8 \\
\hline 6 & 111 & Medium & 24 & Medium & 150.56 & High & 34.91 & 1 \\
\hline 7 & 119 & Medium & 31 & Medium & 160.20 & High & 11.02 & 7 \\
\hline 8 & 82 & Low & 17 & Low & 143.98 & High & 13.90 & 3 \\
\hline 9 & 147 & Medium & 17 & Low & 159.05 & High & 13.28 & 4 \\
\hline 10 & 23 & Low & 4 & Very Low & 65.84 & Medium & 6.96 & 10 \\
\hline
\end{tabular}

Based on Table 4, it can be projected that traffic problems may concentrate the most in zone 6, zone 2, and zone 8 as they rank 1,2, and 3, respectively. Figure 1 and 2 depict the current urban spatial structure and the proposed one, respectively. 


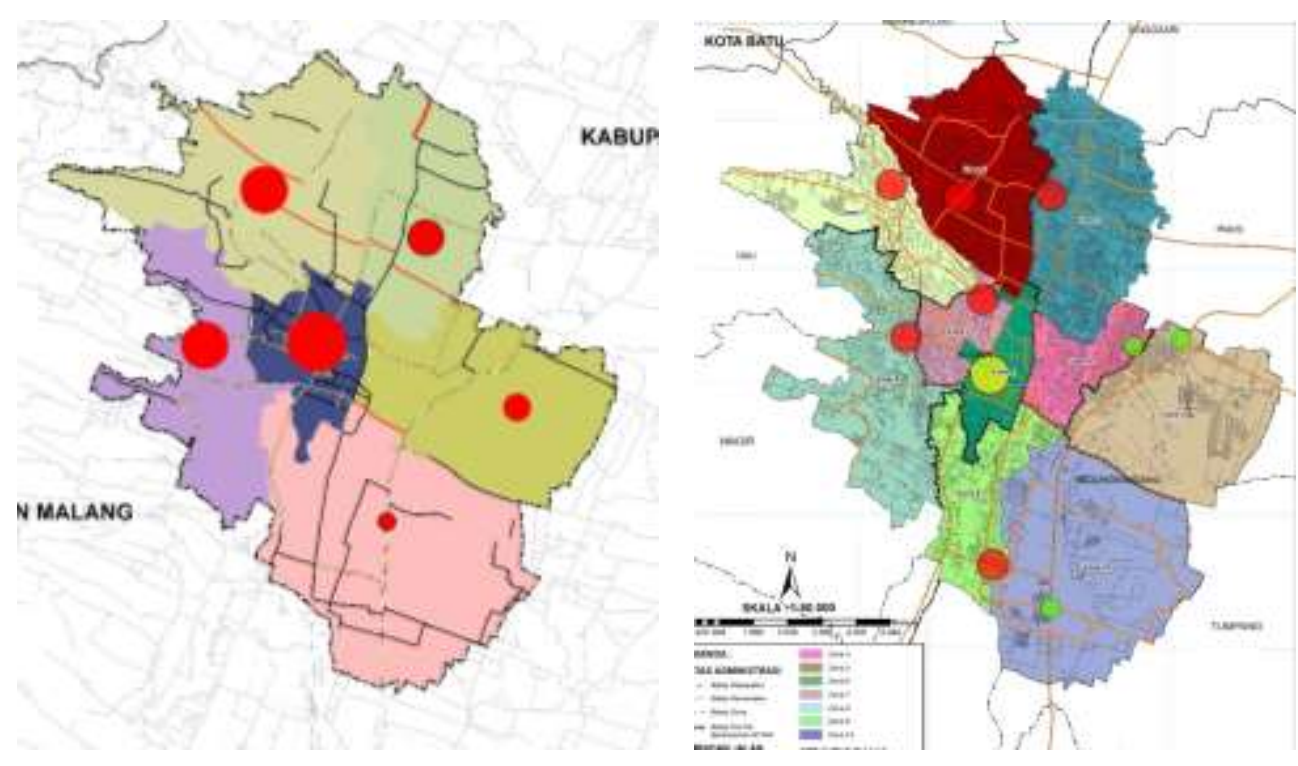

Fig. 1. Malang's urban spatial structure Fig. 2. Malang's proposed urban spatial structure according to RTRW

Unlike the former hierarchy calculation, the proposed calculation provides a more accurate positioning of transport problem projection (Figure 2). Following the city's CBD (Zone 6) as the most congested area is the area surrounding Universitas Brawijaya (Zone 2) and the area around Dieng Plaza (Zone 8). These zones, based on a recent survey of traffic congestion points, are amongst the worst. During the city's peak hours and weekends, the roads' level of service reach the level D or E. Figure 3 explains the spatial distribution of traffic congestion in Malang.

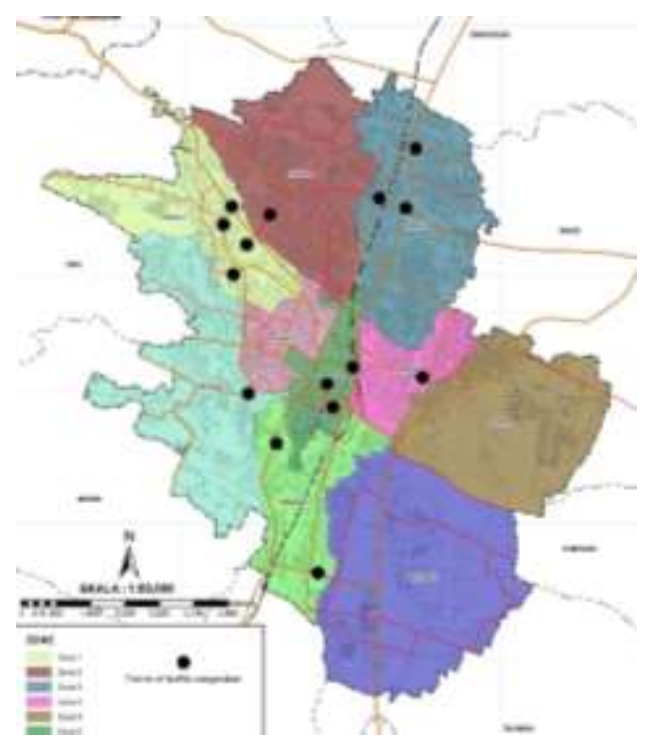

Fig 3. Points of traffic congestion in Malang 
Figure 3 shows that there is a link between urban spatial structure and transport movement. It appears that the identified congested locations are ones that function as activity centers in the urban structure hierarchy (Figure 2). By comparing the two figures, it can be said that the theories that postulates the relationship between the urban spatial structure and travel movement patterns are valid enough to be applied in Malang. Therefore, this could be the basis for determining the appropriate transport strategy to handle the problems that occur. Strategies could be prioritized to aim the designated centres according to the centrality index (Table 4).

\section{Conclusion}

Using a similar approach in determining the hierarchy of urban spatial centre to the RTRW document, this paper re-assessed the hierarchy based on a smaller size of units of area. With more centres determined, this research allowed a more detailed trajectory of travel movement within the city. For instance, the area around Universitas Brawijaya, which was originally over seen, was now obvious in need of a more serious transport solution due to its relatively higher rank in the centrality index. Looking at the points of traffic congestion in Malang, and building upon the findings of this research, it can be suggested to the local government of Malang that there must be a prioritization of transport improvement accordingly to the hierarchy of urban spatial structure.

\section{Reference}

1. Ekawati, N., Soeaidy, M., \& Robawanto, H Kajian Dampak Pengembangan Pembangunan Kota Malang Terhadap Kemcetan lalu Lintas (Studi pada Dinas Perhubungan Kota Malang). Jurnal Administrasi Publik (JAP), 129-133. (2014).

2. Dinas Perhubungan Kota Malang. Tataran Transportasi Lokal. Malang: Dinas Perhubungan Kota Malang. (2015).

3. Setiawan, B. Pengaruh Struktur Ruang Kota Terhadap Pola Pergerakan di Kota Semarang dan Kota Surakarta. Skripsi. Tidak dipublikasikan. Semarang: Universitas Diponegoro. (2004).

4. Tondabola, L. Pengembangan Struktur Ruang: Mereduksi Mobilitas Perkotaan. Jurnal Media Matrasain, 73-79.Ridwan, M. Measurement Scale of Research Variables (pp. 2431). Bandung: Alfabeta. (2015).

5. Curtis, C. The Windscreen World of Land Use Transpot Integration. Jurnal Town Planning Review, 423-453. (2005).

6. Bento, A., Cropper, M., Mobarok, A., \& Vinha, K. The Effects of Urban Spatial Structure on Travel Demand in The United States. Jurnal Review of Economics and Statistic, 466-478. (2005).

7. Tamin, Ofyar Z. Transport Planning and Modeling. Bandung: ITB Bandung. (2000).

8. Greene, D. Urban Subcenter: Recant Trends in Urban Spatial Structure. Jurnal Economic Literature, 1-13. (2001). 